\title{
The Political Economy of Economic Reform
}

\author{
by \\ Allan H. Meltzer \\ Carnegie Mellon University and \\ American Enterprise Institute
}

This topic is both timely and useful. Its usefulness stems from the fact that, while a considerable amount of resources are used to promote economic reform, not much attention has been given to the evaluation and rationale for reform. When do reforms work? Why do they fail?

Contrast the many papers asking why the distribution of income in the United States and other advanced countries has widened and the very little consideration given to the much greater change in the wealth of different nations. Why have per capita incomes in several African countries declined at a time when the world has seen greater increases in per capita income for more people than at any time in recorded history.

The subject is too broad to cover in one short session. I will limit my remarks to two topics: reform in the former Soviet Union and the role of development banks and institutions. The two overlap, of course. The principal development institutions -- the IMF and the World Bank -- are very active in the former Soviet Union.

\section{Development Institutions}

What is the current rationale for international development banks and institutions? At their birth the IMF, the World Bank and other development banks had clear rationales. The IMF was to supervise the fixed exchange rate system. The World Bank was to assist in reconstruction after World War II and to assist in the development of countries that could not borrow because of credit market failures or risk aversion.

Both reasons have lost much of their validity. The fixed exchange rate system disappeared a quarter of a century ago, and the financial problems of poor and developing countries have often resulted from too much rather than too little borrowing. Much of that borrowing has been private 
, loans as in Latin America during the 1980s and Mexico in the 1990s.

The Fund and the Bank have continued to grow and additional development banks have been organized. There is now considerable overlap, without effective competition, between the World Bank and the Monetary Fund and between these two and the regional development banks. Instead of referring to the specific institutions, I will use the term development institutions as a general reference. As the political agenda, particularly the U.S. political agenda, has changed, the development institutions have adopted these agenda items. Instead of seeking development and poverty reduction through helping to develop infrastructure, there are now goals and loans for the alleviation of poverty, protection of the environment, pursuit of greater equality for women and other desirable ends.

There are three, large problems, however. First, organizations staffed with specialists in infrastructure development are poorly equipped to monitor the several additional goals assigned or accepted. Second, the development institutions become development conglomerates without any explicit means of allocating resources among competing ends. Allocation becomes entirely the result of a political process without any clear relation to contributions. We know that most market conglomerates found it difficult to add value to the individual parts where results could be measured by a profit criterion. Development conglomerates, lacking any explicit criterion, are unlikely to add social value by broadening their missions. Third, and most important, development institutions relax countries budget constraints. Whatever the project or proposal may say, marginal funds finance marginal projects. Development banks fund marginal programs. Recognition of that proposition contributes to an understanding of why questions about the effectiveness of development institutions continue to arise.

One of the principal functions of all development institutions is to give advice or counsel. The quality of this advice may be, and often is, very high. Yet, there is an odd feature about the advice. Most often it is tied to lending, particularly in the case with so-called structural adjustment loans. Private consultants charge fees for their advice. Development institutions not only give the advice, often they pay the client state to accept the advice, at least nominally, by 
, offering loans at below market rates for comparable risks. And the client often agrees to the advice, as conditionality for the loan, but in many cases does not achieve the agreed objectives or conditions.

The development institutions have not solved the problem of how to enforce conditionality. After 50 years of experience, the borrowers surely understand that conditionality is a weak constraint. This may explain why studies of conditionality, as reported in the Economist (October 12, 1991), show a decline in compliance overtime.

The most effective way to enforce conditionality is to refuse additional lending or even to call outstanding loans when that option is available. The incentive system in the development banks rewards making loans, so those options are used infrequently. Further, developing countries understand that they can punish visiting officials of development institutions by declining to arrange meetings with high local officials. The representatives of the development institutions must report on their mission. Failure to meet with senior officials is taken as a sign of lack of success. This sanction by the developing countries and the incentive to make or renew loans appears to have been more powerful than the incentive to enforce conditionality.

In the early postwar years, the number of trained economists in development economics was small, perhaps non-existent. Currently, most countries have some, often many, trained economists and technicians. Often the officials of the developing economy include classmates of the officials and economists of the development institutions. Whatever may have been true in the past, there is currently no case for development institutions as a source of knowledge unavailable in the developing countries. And, even if it were true that foreigners have a comparative advantage in supplying advice, there are several private consulting firms willing to provide such advice for a fee. Why should the development institutions give, or even subsidize, services that can be supplied competitively.

At the general level "good advice" consists of such propositions as: open the economy, restrain government spending and budget deficits, reduce the burden of regulation, improve the efficiency of the tax system, and similar propositions. Application to a country requires 
. knowledge of local institutions and customs, where local economists would seem to have an advantage.

The principal impediment is, more often than not, political willingness, not lack of knowledge. Here the development institutions may have an advantage. They can offer loans to ease the transition. But the loans can also be used, as they often are, to avoid making politically difficult decisions. Loans relax the budget constraint. It is an open question, on which little research has been done directly, whether (or perhaps when) foreign aid or subsidized lending provides greater incentives for reform or for delay. Partial and indirect evidence from studies of the effectiveness of conditionality suggest that both processes are at work.

In a recent paper, Jakob Svennson models some of these processes. He finds:

"First, as foreign aid to a large extent can be seen as general budget support, the paper provides an explanation for why increased disbursements do not necessarily lead to higher provision of public goods, a result in accordance with empirical findings... Second, I show that the mere fact that the donor is expected to allocate aid according to the future needs of the recipient... may increase rent dissipation and reduce the expected number of periods in which efficient policies can be sustained." Svennson (1996).

\section{Reforming Russia}

Many of the issues I have discussed in general are applicable, I believe, to the case of Russia and other former Soviet states. These countries include some of the largest current and prospective borrowers from several of the development institutions.

I believe that reform efforts in these countries have been hampered by the emphasis on economic stabilization with little recognition of the political economy of reform. I willingly grant that the standard stabilization package mentioned earlier -- open economy, fiscal stabilization, control of inflation, etc. -- is important. The development institutions have correctly emphasized these policy issues. In Russia, however, deficit and inflation control have included non-payment 
- of wages to workers, state employees, and the military. This creates an unstable, risky and unsustainable situation.

The development institutions have also failed by their neglect of what I call the Hayekian infrastructure. Hayck emphasized that capitalism, or the market economy, requires an institutional infrastructure. The rule of law, the protection of property rights, hence an independent judiciary are part of this structure. There must be a commercial code and courts to enforce delivery according to contract, and a bankruptcy law to apportion assets in the event of failures. Accounting systems and financial systems are other parts of this infrastructure. It is notable that these Hayekian insights have been emphasized by outsiders like Hernando de Soto much more than by the staffs or officials of development institutions.

The development institutions operating in Russia and other parts of the former Soviet Union gave much attention to freeing market prices and achieving macro stability but little attention to developing the Hayekian infrastructure. Despite the lesson for China, where granting limited property rights in agricultural land fostered development, private property in land has been relatively slow to occur. Moreover, private property rights, enforced contracts and the rule of law have either been slow to develop or have been developed with help from criminal elements. This is no basis on which to build a well-functioning market economy.

Of course, everything cannot be done at once if only because the time of officials is a scarce resource. My criticism of the development institutions is not just that they have chosen different priorities. I believe they have neglected some necessary conditions of efficient market economies.

A political economy view recognizes two processes that are at work: simultaneous processes and recursive processes. Meltzer (1993) Decisions about money, exchange rates, prices, wages and interest rates -- the elements of the stabilization package -- are interdependent. Optimal decisions about these variables must be made together, simultaneously. If some of these variables are put on the path to stability, while others are not, the result will be non-optimal and possibly inconsistent. Additional adjustments must be made with consequences for anticipations and 
outcomes.

Other reforms -- including especially the Hayekian infrastructure -- are recursive. For example, there is a recursive relation between the rules for contrasts, enforcement, financial structure, accounting and valuation, and property rights and the properties of the market economy that results. The institutions of the market system are not much affected by the sets of prices that emerge, but the converse is not true. Rules and institutions influence how the market develops, and the price elasticity of supply functions and the value of state enterprises.

By neglecting the Hayekian infrastructure, the development institutions have encouraged the type of development often called gangster capitalism in Russia and put Russia on a path far less than optimal and one from which it will depart only at high cost. By failing to pay wages to employees and soldiers, Russia, in particular, risks revolt or political disruption. The future of capitalism or the market economy in Russia and other former Soviet republics will continue to be shaped by these errors.

\section{References}

Meltzer, Allan H., (1993). "Comment: Socialist Economic Transformation," Lournal of Economic Perspectives.

Svennson, Jakob, (1996). "Collusion Among Interest Groups: Foreign Aid and Rent

Dissipation". Preprint, Institute for International Economic Studies, Stockholm, (May). 